\title{
Asset bubbles in explaining top income shares
}

\author{
Saikat Sarkar ${ }^{1}$ Matti Tuomala ${ }^{2}$
}

Received: 1 August 2018 / Accepted: 19 February 2021 / Published online: 23 May 2021

(C) The Author(s) 2021

\begin{abstract}
This paper considers the role of asset price bubbles (crashes) as an important determinant in seeking a further explanation for top income shares. The asset price bubbles caused at least in part by monetary policies, along with other determinants such as top tax rates and innovativeness are the important drivers to explain the surge in top income shares. The empirical results show that correlation between asset bubbles and top inequality is positive and significant. The regression coefficient of stock and housing market bubbles have a positive effect on top income shares, while the stock and housing market crashes fail to reduce the surge in top income shares. In sum, as the asset markets grow, the share of income going to those at the very top increases and the accumulation of income accelerates if the duration of bubbles expands. Concentration of income at the very top is much more important when capital gains are counted as income.
\end{abstract}

Keywords Top income shares · Bubbles and crashes · Innovations · Top tax rates

\section{Introduction}

An increase in top income shares worldwide and particularly in developed countries is welldocumented $^{1}$. Economists have formulated several hypotheses about causes of increasing top income inequality. However, no consensus has been reached as to the main underlying forces behind this surge in top income inequality.

Top income share series constructed for the USA by Piketty-Saez $(2007,2014)$ suggests that bubbles seem to occur during a period when top income shares have rapidly increased. The dot.com bubble in stocks in 2000 occurred when top income inequality (including capital gains) hit a level very similar to that in 1929 , particularly for the top $0.01 \%$. The rise

\footnotetext{
${ }^{1}$ See the World Wealth and Income Database (WID).

Saikat Sarkar

ssarkar@mta.ca

Matti Tuomala

matti.tuomala@tuni.fi

1 Ron Joyce Center for Business Studies, Mount Allison University, 62 York St, Sackville, NB E4L 1E2, Canada

2 School of Management, Tampere University, Tampere, Finland
} 
in top income inequality accelerates from $1995-2000$ as the dot.com bubble is inflating. A similar concentration of income is evident as the housing bubble is inflating in 2003-2008. It was not so until the mid-1980s. Income concentration among rich decreases during the period before the mid-1980s.

Income concentration among the rich observed in top income shares, constructed by the World Wealth and Income Database (WID) of the Paris School of Economics, accelerates also in most of the advanced countries in the later part of the 1990s, drops somewhat just after the crash of the dot.com bubble in 2000, and then comes roaring back again during the housing bubble period mostly in 2003-2008. Figures 7 and 8 also display similar evidence, which is presented in online Appendix B.3. Hence bubbles seem to occur during a period when income is becoming increasingly concentrated at the top. Do large asset price bubbles cause for increasing top income shares? The effect of bubbles (crashes) on top income shares is likely to be different in year one vs. year three of a bubble (crash). The duration of bubbles (crashes) might play an important role in concentrating income among the rich through accumulating capital gains. Unfortunately, data on capital gains is not available in all countries studied here, despite being a significant driver of top incomes (see Fig. 1). The following figures provide preliminary support for this view.

Figure 1a and $\mathrm{b}$ plot the change in top income shares against durations of the stock market bubble (crash) for all countries considered here. Figure 1(c) and (d) in turn plot the change in top income shares and durations of the housing market bubble (crash) for all

a
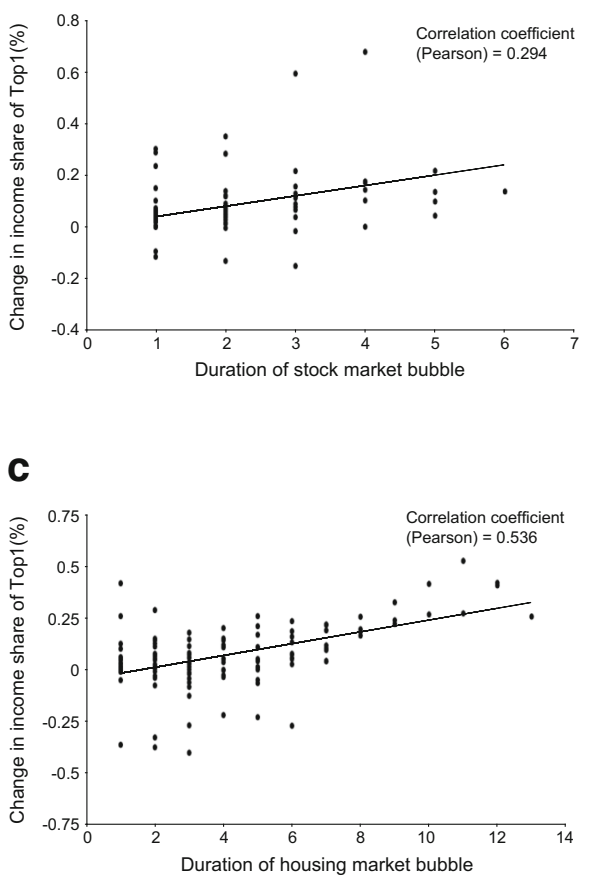

b

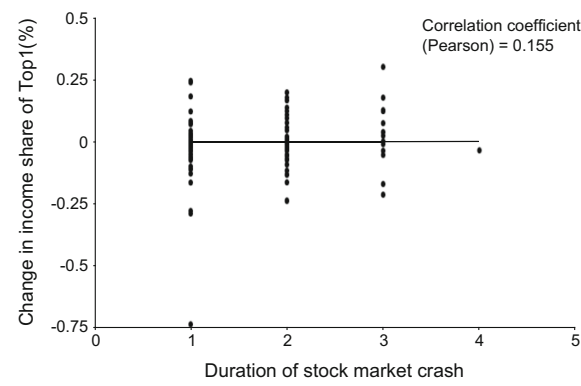

d

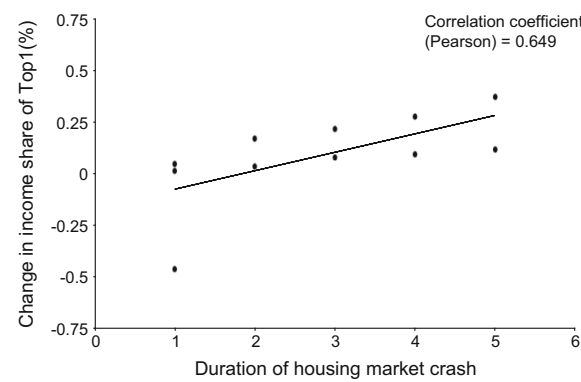

Fig. 1 Relationship between top income shares excluding capital gain and duration of the explosive episodes in the asset markets. Figure 1a and b include Australia, Canada, Colombia, Denmark, Finland, France, Germany, India, Ireland, Italy, Japan, Korea (R), Malaysia, Netherlands, New Zealand, Norway, Singapore, South Africa, Spain, Sweden, Switzerland, UK, and USA. Figure 1c and d include all countries except Colombia, India, Malaysia and Singapore 
countries except Colombia, India, Singapore and Malaysia. Figure 1a shows that there is a positive correlation between the change in top income shares and durations of the stock market bubble. Similarly, the relationship between the housing bubble durations and change in top income shares is positive, presented in Fig. 1c. Figure 1a and c show that the change of top income shares is increasing with duration of the asset bubble and this evidence is very conspicuous in the case of the housing market. Figure $1 \mathrm{~b}$ and $\mathrm{d}$ portray the relationship between the durations of market crash and the change in top income shares, which are positively correlated. Preliminary results show that both the stock crash durations and the housing crash durations fail to reduce the surge in top income shares by deflating the asset prices.

Figure 1a-d suggest that there is a good reason to consider the role of asset price bubbles (crashes) as an important determinant in seeking a further explanation for top income shares. The asset price bubbles are caused at least in part by monetary policies, along with other determinants of the surge in top income shares such as top tax rates and innovativeness.

What has happened repeatedly in recent decades is that monetary authorities in rich countries, especially in the USA, have allowed banks to lend more through deregulation and loose monetary policy. Disproportionately it has gone to increase the value of stocks and fixed resources (buildings, real estate, etc). It appears that the flood of liquidity has disproportionately gone towards creating financial wealth and inflating asset bubbles. A bubble can lead to an increase in wealth for an extended period. Whenever these assets boom, the share of income going to those at the very top increases. That is because people at the very top of income scale tend to hold much of their wealth in stocks and fixed resources. Hence, they benefit disproportionately from aggressive monetary policies. On the other hand, those who hold wealth that can be used for collateral see their assets go up in price and become wealthier. When the boom goes bust, top shares drop somewhat, but then they come roaring back, e.g. by quantitative easing, even higher with the next asset bubble ${ }^{2}$. Indeed, it is easy for capitalist economies to generate such bubbles ${ }^{3}$.

Top income tax rates were significantly reduced in rich countries after the 1970s. Their variations are relatively well associated with changes in top pre-tax income shares across rich and emerging countries. Piketty et al. (2014) argue that with lower tax rates, the CEO has a much greater incentive in the bargaining process with the company. They, rather than the tax authority, will receive the rewards from being successful. Piketty et al. (2014) also show that there is a clear correlation between the drop-in top marginal tax rates and the surge in top income shares.

Other studies argue that the increasing importance of innovation is magnifying innovationbased rents that contribute to increasing the income share of the top income groups. In their paper Aghion et al. (2019) argue that; patenting and top income inequality in the US and other developed countries over the past decades, tend to follow parallel evolution. They develop a simple Schumpeterian growth model to explain why increased R\&D productivity increases the top income share. Schumpeter argued that competition for new products and cheaper production processes is at the heart of market economy. Schumpeter believed that this competition pressure leads to high levels of innovation. Aghion et al. (2019) argue that

\footnotetext{
2"We now know that the economic expansion of 2003-2007 was driven by a bubble. You can say the same about the latter part of the 90s expansion; and you can in fact say the same about the later years of the Reagan expansion, which was driven at that point by runaway thrift institutions and a large bubble in commercial real estate". Krugman 2013

${ }^{3}$ It is a fact that should be obvious from the historical record, but which has also been confirmed in theoretical models.
} 
"overall, our findings are in line with the Schumpeterian view whereby more innovation-led growth should increase top income shares (which reflect innovation rents)".

Guellec and Paunov (2017) examine the link between digital innovation (defined as new products and processes based on or embodied in software code and data, in and beyond IT industries) and top income shares. Specifically, their paper focuses on inequality generated from market rents ${ }^{4}$ accruing to top executives, key employees, and shareholders, with little benefit to the average worker.

The objective of this paper is to show how the bubble economy environment affects top income inequality. In other words, this paper examines the role of bubbles in explaining an increase of top income inequality, using two measures of top income inequality: the top $0.1 \%$ share in total income, and the top $1 \%$. The data on top income inequality comes from the WID. The empirical analysis starts by exploring links between asset bubbles and crashes and top income inequality measures. Later the Feasible Generalized Least Squares (FGLS) method is used to analyse the transitory effect of asset bubbles and crashes on top income shares while controlling the effect of addition potential determinants on top income shares including, among others, economic innovation, financial development, top marginal tax rates, government expenditure, economic growth, and trade openness. The effect of asset bubble durations on top income inequality is also analysed. In an extension of the analysis, the indicator variables of bubbles and crashes are substituted with continuous variables to re-examine the link between asset bubbles a nd top income shares.

The main findings of this research can be summarized as follows: the two top inequality measures considered in this paper and asset bubbles are positively and significantly correlated. Regression analysis states that the coefficient of stock market bubble has a positive effect on top income shares while the stock market crash fails to reduce the surge in top income shares. The variable innovation, measured by the annual flow of patents, has a positive effect on top income shares. Moreover, top marginal tax rates plays an important role in impeding the surge in top income shares. In summary: asset market bubbles as well as top marginal tax rates and innovation-led growth are among the most important determinants of the increasing top income shares that many developed countries have experienced over the past decades.

The paper is structured as follows. Section 2 provides the data description and descriptive statistics whilst the empirical model is discussed in Section 3. The results are discussed in Section 4. Robustness checks and extensions are analysed in Section 5. Concluding comments are provided in Section 6.

\section{Data description}

The unbalanced annual panel data consists of 23 countries grouped into 3 regions: AngloSaxon (Australia, Canada, New Zealand, UK and USA), developed (Denmark, Finland, France, Germany, Ireland, Italy, Japan, Netherlands, Norway, Korea(R), Singapore, Spain, Sweden and Switzerland) and emerging (Colombia, India, Malaysia and South Africa) for the period of 1980 to 2012 . There are some missing values and a linear interpolation technique is used to fill out those gaps in the data, but only when the gap of the missing period is not more than five consecutive years. This section describes all the variables and

\footnotetext{
${ }^{4}$ Kurz (2017) estimates that almost $80 \%$ of the equity value of publicly listed companies in USA is associated with rents, almost a quarter of value added. Much of those rents are linked to the IT sector.
} 
Table 1 Descriptive statistics of key variables

\begin{tabular}{|c|c|c|c|c|c|c|c|}
\hline & Top1 & Top0.1 & $\begin{array}{l}\text { S.market } \\
\text { bubble }\end{array}$ & $\begin{array}{l}\text { S.market } \\
\text { crash }\end{array}$ & $\begin{array}{l}\text { H.market } \\
\text { bubble }\end{array}$ & $\begin{array}{l}\text { H.market } \\
\text { crash }\end{array}$ & $\begin{array}{l}\text { S.bubble } \\
\text { duration }\end{array}$ \\
\hline Observations & 632 & 411 & 632 & 632 & 486 & 486 & 632 \\
\hline Mean & 9.06 & 2.89 & 0.12 & 0.21 & 0.27 & 0.02 & 0.27 \\
\hline $\mathrm{SD}$ & 3.39 & 1.50 & 0.33 & 0.41 & 0.44 & 0.15 & 0.86 \\
\hline Manimum & 3.49 & 0.77 & 0 & 0 & 0 & 0 & 0 \\
\hline \multirow[t]{2}{*}{ Maximum } & 21.3 & 8.36 & 1 & 1 & 1 & 1 & 7 \\
\hline & $\begin{array}{l}\text { S.crash } \\
\text { duration }\end{array}$ & $\begin{array}{l}\text { H.bubble } \\
\text { duration }\end{array}$ & $\begin{array}{l}\text { H.crash } \\
\text { duration }\end{array}$ & $\begin{array}{l}\text { Cum } \\
\text { return }\end{array}$ & $\begin{array}{l}\text { H.Cum } \\
\text { return }\end{array}$ & $\begin{array}{l}\text { Innov- } \\
\text { ation }\end{array}$ & $\begin{array}{l}\text { GDP } \\
\text { per capita }\end{array}$ \\
\hline Observations & 632 & 486 & 486 & 632 & 486 & 632 & 632 \\
\hline Mean & 0.34 & 1.10 & 0.06 & 0.16 & 0.05 & 1.61 & 10.22 \\
\hline $\mathrm{SD}$ & 0.73 & 2.31 & 0.47 & 0.42 & 0.13 & 2.97 & 0.67 \\
\hline Manimum & 0 & 0 & 0 & -0.76 & -0.34 & 0 & 7.13 \\
\hline \multirow[t]{2}{*}{ Maximum } & 4 & 13 & 5 & 3.29 & 0.50 & 14.73 & 11.34 \\
\hline & $\begin{array}{l}\text { Finan. } \\
\text { dev. }\end{array}$ & $\begin{array}{l}\text { Govt. } \\
\exp \end{array}$ & $\begin{array}{l}\text { Open } \\
\text {-ness }\end{array}$ & $\begin{array}{l}\text { T. marg. } \\
\text { tax rate }\end{array}$ & $\begin{array}{l}\text { Banking } \\
\text { crisis }\end{array}$ & $\begin{array}{l}\text { Popula- } \\
\text { tion }\end{array}$ & \\
\hline Observations & 632 & 632 & 632 & 632 & 632 & 632 & \\
\hline Mean & 1.42 & 0.18 & 0.71 & 0.46 & 0.18 & 10.11 & \\
\hline $\mathrm{SD}$ & 0.67 & 0.04 & 0.67 & 0.14 & 0.38 & 1.38 & \\
\hline Manimum & 0.24 & 0.08 & 0.12 & 0.11 & 0 & 7.99 & \\
\hline Maximum & 4.03 & 0.30 & 4.39 & 0.93 & 1 & 13.80 & \\
\hline
\end{tabular}

their sources in three parts. The definition and sources of top income shares and explosive episodes (i.e., bubble and crash) of the asset markets are presented in the first subsection (2.1) and in the second subsection (2.2), respectively. The last subsection describes the definition and sources of traditional determinants of top income shares (2.3). Descriptive statistics, variable descriptions, data sources and data availability are given in Table 1, Appendix Tables 6 and $7^{5}$.

\subsection{Top income shares}

The data on top shares of total income both including ${ }^{6}$ and excluding capital gain ${ }^{7}$ are used in the econometric analysis. Top income shares data are downloaded from the World Wealth and Income Database (WID) of the Paris School of Economics. Top 0.1\% income share and top $1 \%$ income share are the preferred measure of top income inequality. The WID database is a valuable source for describing the long-run trend in top income shares and provides a comparable series of top income shares across countries, although potential inconsistencies regarding different income definitions, income tax units, and changes in legislation at different points in time across countries cannot be completely avoided (see Morelli and Atkinson (2015),

\footnotetext{
${ }^{5}$ Correlation coefficients of thses variables are reported in online Appendix A, Table B1.

${ }^{6}$ Countries are Canada, Germany, Japan, Spain and Sweden, USA.

${ }^{7}$ Countries are Australia, Canada, Colombia, Denmark, Finland, France, Germany, India, Ireland, Italy, Japan, Korea (R), Malaysia, Netherlands, New Zealand, Norway, Singapore, South Africa, Spain, Sweden, Switzerland, UK, USA.
} 
Piketty et al. (2014) and Atkinson (2005), for details). Nonetheless, the choice of focusing on the country's richest decile is important, as the accumulation of income at the top is related to the performance of the financial markets.

Figures 7 and 8 portray the dynamics of top 1\% income shares excluding capital gain, which is presented in online Appendix B.3. The rise in top $1 \%$ income shares accelerates over the period of 1996-2000 and a similar concentration of income can also be seen in 2005-2008 in developed countries. These two time periods are considered as the well-known dot-com bubble and housing bubble, respectively. After the burst of the dot-com bubble i.e., in the crisis period (2001-2002) the rise in income acceleration suffers moderately. Similar evidence of decrease in the surge of top income shares could also be found over the period of 1990-1995 for some developed countries.

\subsection{Bubble and crash episodes in stock and housing markets}

The explanatory variables, stock market crash and banking crisis, are collected from Carmen M. Reinhart's website and updated from the Global Financial Development database of World Bank (Reinhart and Rogoff (2011) for details). The main variables, stock market bubble, housing market bubble, and housing market crisis are based on the Generalized Sup Augmented Dickey-Fuller test (GSADF), a statistical procedure proposed by Phillips et al. (2015). The GSADF procedure is recommended for high frequency data. Due to the unavailability of monthly data, quarterly real housing price indexes of 19 countries $^{8}$ and quarterly real stock-price composite indexes of 23 countries from the Global Financial Database (GFD) are used to detect the periods of bubble (crash) episodes.

The idea of the GSADF test is based on the Random Walk Hypothesis. This test presumes that the bubble injects an explosive component into prices and creates exuberance in the asset market. In the presence of a bubble, buyers are willing to pay prices increasingly higher than the fundamental-based price because they expect to be compensated through future price increases. Then, the asset prices deviate from a random walk to an explosive regime. The moment of deviation from a random walk could be regarded as the origin or collapse of the bubble.

The estimated test statistics of the GSADF for each country are based on autoregressive lag length $k=1$, reported in Panel A of online Appendix Table B ${ }^{9}$. The finite critical value of the GSADF test is also presented in Panel B of online Appendix Table B1. Finite sample critical values are obtained by generating 2,000 random walk processes with $\mathrm{N}(0$, 1) errors ${ }^{10}$. The GSADF test shows strong evidence of bubble (crash) episodes present in real housing price and in real stock price index in most of the countries. However, the GSADF test is statistically insignificant at the 5 percent level for the Italian housing price and for the Korean housing price index. The GSADF test is also statistically insignificant at

\footnotetext{
${ }^{8}$ Australia, Canada, Denmark, Finland, France, Germany, Ireland, Italy, Japan, Korea (R), Netherlands, New Zealand, Norway, South Africa, Spain, Sweden, Switzerland, UK, USA. The data were downloaded in June 2016 from the website, https://www.dallasfed.org/institute/houseprice. For a detailed description of the sources and methodology issues see Mack and Gracia (2015).

${ }^{9}$ Other researchers also assumed an integrated process of order 1 (see Phillips et al. (2015), Pavlidis et al. (2015), and Homm and Breitung (2012) among others). For robustness, we also estimated the GSADF test with autoregressive lag length $\mathrm{k}=2$ and $\mathrm{k}=3$. Our findings about the presence of explosive behaviour and the origin and collapse dates of explosive episodes in the price indexes do not appear to be very sensitive.

${ }^{10}$ International house price database of the Federal Reserve Bank of Dallas also includes SADF, GSADF, and BSADF test-statistics for real house prices for all available countries together with the corresponding critical values (see Pavlidis et al. (2015) for details).
} 
the 5 percent level for Italy, Malaysia, Norway and for Singapore stock price indexes. That means that the GSADF test fails to find evidence of bubble (crash) episodes in the quarterly real housing price indexes for Italy and Korea $(\mathrm{R})$ and quarterly real stock price indexes for Italy, Malaysia, Norway, and Singapore. However, other researchers find evidence of bubble (crash) episodes in Malaysia and Singapore stock indexes based on monthly data (see Chen and Quan 2013). The GSADF test may not be appropriate in detecting bubble (crash) episodes in low frequency data but, it is worthwhile to note that the literature of explosive behaviour in the asset prices are based on high frequency data with a few exceptions and most of the scholars, applied the GSADF test on monthly or daily data (see Phillips et al. (2015), Zeren and Yilanci (2019), and Corbeta et al. (2018) among others).

Next, the time series of the backward Sup Augmented Dickey-Fuller (BSADF) test against the 95\% Sup Augmented Dickey-Fuller (SADF) critical value, obtained from Monte Carlo simulations with 2,000 replications, along with the real asset price index, is plotted to locate the origin or collapse of bubble (crash) episodes (see Phillips et al. (2015) for more details). The starting point of a bubble (crash) episode is defined as the date at which the BSADF sequence crosses the corresponding critical value from below. Similarly, the ending point of a bubble (crash) episode is defined as the date at which the backward SADF sequence crosses the corresponding critical value from above. These figures (reported in online Appendix B.1 and B.2) successfully detect the start and end dates of bubble periods in real stock price indexes, but the procedure proposed by Phillips et al. (2015) fails to recognize some of the well-known financial turmoil, at least for quarterly real asset price indexes (see figures in online Appendix B.1). Despite limitations, the date-stamping procedure works well in recognizing the start and end dates of bubble episodes in asset prices indexes. GSADF also recognises some of the crash episodes in the housing market. For example, it also successfully detects the start and end date of crash periods in the housing market for Japan (Y2002-Y2006, Y2014), Germany (Y2004-Y2008) and the Netherlands (Y2012-Y2013) (see figures in online Appendix B.2). To develop the Japanese housing crash index, a value equal to 1 is set for years 2002 - 2006 and for year 2014, otherwise it equals to zero. The same procedure is used in developing stock market bubble, housing market bubble and crash indexes for other countries. The yearly crash and bubble variables contain only binary values which will be available for the period of 1984-2012. All nonoverlapping bubble and crash episodes are reported in online Appendix Table B2. However, alternative measures of crash and bubble variables, and cumulative real asset returns are available for the whole sample period (1980-2012).

\subsection{Traditional determinants of top income shares}

As mentioned in the introduction there are many forces that may be responsible for the surge of top income shares. For example, financial development promotes economic development usually favouring the rich (see Roine et al. 2009). The rise in top income shares might accelerate due to a decrease in the top marginal tax rates on wage income (Atkinson and Leigh (2013)). Therefore, financial development, economic growth rate, top marginal tax rate, central government expenditure, banking crisis ${ }^{11}$, and trade openness are used as control variables in the econometric analysis. All the control variables are available for the

\footnotetext{
${ }^{11}$ A detailed discussion of the link between banking crises and top income shares can be found in Morelli (2018).
} 
whole sample period (1980-2012) except for Financial development. Financial development is not available for the period of 2009-2010 in Canada and for 2011 in New Zealand. Variable descriptions and data sources are given in Appendix Table 6.

\section{Empirical model}

Standard panel model analysis can help us unravel some of the economic factors which might trigger the recent uptrend of top income inequality. This approach has already been applied by Atkinson and Leigh (2013) and Roine et al. (2009). The fixed effect panel regression equation is described as follows:

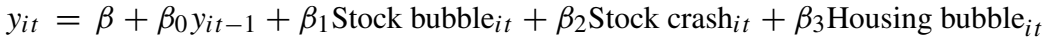

$$
\begin{aligned}
& +\beta_{4} \text { Housing }_{\text {crash }_{i t}}+\beta_{5} \text { Innovation }_{i t}+\beta_{6} \text { GDPpc }_{i t}+\beta_{7} \text { Financial dev }_{i t} \\
& +\beta_{8} \text { Government expenditure }_{i t}+\beta_{9} \text { Openness }_{i t}+\beta_{10} \text { Top tax rate }_{i t} \\
& +\beta_{11} \text { Population }_{i t}+\xi_{i}+t+\epsilon_{i t}
\end{aligned}
$$

where $i$ refers to a country and $t$ to year, and $\beta$ is the constant term. Fixed country effects are denoted by $\xi_{i}$ (traditional dummy variables), and the $\epsilon_{i t}$ are traditional error terms. The fixed country effects should consider factors that stay constant over time within each country. Variable $t$ captures the fixed time effects.

The variable $y_{i t}$ represents the top income shares ${ }^{12}$. The stock market and housing market bubble variables are equal to one for the exuberance period, otherwise, equal to zero. Similarly, stock market crash and housing market crash are binary variables equal to one for the period of a crash, otherwise equal to zero. We are interested in coefficient values of bubble variables and crash variables. It is expected that both the bubbles accelerate to elevate the income of the rich and the coefficient of the crash variables will have a negative sign. The control variables are innovation, gross domestic product per capita, financial development, trade openness, top marginal tax rate, government expenditure, and population. We also control time trend and time invariant country effects. This does not mean that we have fully addressed potential endogeneity problems.

The most common way to estimate fixed effects models is to remove the fixed effect by time demeaning each variable (the so-called within estimator). However, the inclusion of the lagged dependent variable might be problematic. It could be correlated with the unobserved fixed effects and generate biased estimates. This bias is reduced when the sample size is large (Nickell 1981). The assumption of no autocorrelation in the error terms does not necessarily hold even after the inclusion of $y_{i t-1}$ and the variance of the error could be heteroskedastic. The standard way of dealing with the dynamic panel data problem is to use GMM-procedures (Arellano and Bond (1991) or Arellano and Bover (1995)). However, these GMM-procedures are not appropriate in a setting with small $\mathrm{N}$ (country) and large $\mathrm{T}$ (time) such as ours (see Roodman 2007). So we apply Feasible Generalized Least Squares method (FGLS) and allow for heteroskedasticity in the error terms (see Roine et al. 2009) for details). However, others used heteroskedasticity-and autocorrelation consistent (HAC) procedures while estimating their model (see Bertrand et al. (2004) and Atkinson and Leigh (2013)).

\footnotetext{
${ }^{12}$ First difference FGLS model could be an alternative way to analyse the determinants of top income shares. This method reduces the problem of non-stationarity issues subtantially. However, we have applied ADF test on top income shares excuding capital gain and found that the series is not non-stationarity.
} 


\section{Detailed empirical results}

This section discusses the empirical results in detail. An overview of the data is reported in Table 1 and the impact of asset market bubbles (crashes) on top income shares from estimating the full model (equation (1)) is represented in Table 2. The linkage between top income shares and the duration of bubble (crash) episodes which is measured by the year-to-burst dummy, is presented in Table 3. The last two columns of both Tables 2 and 3 emphasize the relationship between capital gains and bubble (crash) of the asset markets.

Panel A and Panel B of Table 1 illustrate the descriptive statistics and the correlation coefficients of all the variables, respectively. Top $1 \%$ share has a higher mean (9.06) and standard deviation (3.39) in comparison to the mean (2.89) and variance (1.5) of top $0.1 \%$ share. The correlation between top income inequality, which is presented by top $1 \%$ and top $0.1 \%$ shares in total income, and housing market bubble is positive. Table 1, Panel B also represents the correlation between financial development, stock market and housing market bubbles. They are positive and statistically significant at the 5 percent level. Financial development and GDP per capita are likely to be correlated with banking crisis. However, correlation coefficients between these variables are not statistically significant ${ }^{13}$.

The impact of asset bubbles (crashes) on top income shares is shown in Tables 2-3. According to the estimates of the regression model (1), both stock market and housing market bubbles relate positively to top income shares. The coefficient of stock market bubble is 0.102 for top $0.1 \%$ share in total income excluding capital gains. The effect of housing and stock market bubbles on top income inequality is much more profound for the case of top income shares including capital gains. The coefficients of housing and stock market bubbles are statistically significant at the 5 percent level. Table 2 reports that holding the influence of other variables constant, on average, the top 1\%'s share (including capital gains) goes up by 0.349 percentage points and the top $0.1 \%$ 's share (including capital gains) goes up by 0.266 percentage points during bubble episodes in comparison to the non-bubble episodes. However, the effects of the stock market crash as well as the housing market crash on top income shares are not statistically significant. Therefore, both housing and stock market bubbles have a positive impact on top income shares, and as a result top income inequality rises during the bubble episodes in comparison to the non-bubble episodes.

The impact of duration of bubble (crash) episodes on top $0.1 \%$ and top $1 \%$ shares in total income are reported in Table 3. The coefficient of stock bubble duration is 0.030 for top $0.1 \%$ share in total income excluding capital gains. The coefficients of stock bubble duration and housing bubble duration are 0.242 and 0.174 for top $1 \%$ and top $0.1 \%$ shares including capital gains, respectively. All these estimates are statistically significant at the 5 percent level. These estimates show that holding the influence of other variables constant, on average, the top $1 \%$ 's share goes up by 0.242 percentage points and the top $0.1 \%$ 's share goes up by 0.174 percentage points if the length of the bubble duration extends to 1 year.

To summarize, as the asset markets boom, the share of income going to those at the very top increases and the accumulation of income accelerates if the duration of bubbles expands. Concentration of income at the very top is much more important when capital gains are counted as income.

\footnotetext{
${ }^{13}$ Calderon and Chong (2001) report that financial development generally leads to economic growth. Klomp (2010) also reports that high credit growth, a negative GDP growth and a high real interest rate are on average the most important causes of a banking crisis.
} 
The choice of whether capital gains are counted as income or not has a material impact on the study of top income inequality. It is well documented that the share of capital income is large, and in many countries capital gains are taxed at a lower flat rate. As a result, the dynamics of capital gains vary significantly over time in response to both economic and tax policy changes. However, the benefits of capital gains are concentrated among a relatively small number of people. Unfortunately, data on capital gains are not available in most of the countries considered here, despite capital gains being a significant driver of top incomes. The last two columns of Tables 2-3 report the impact of bubbles (crashes) on the share of capital gains. The coefficients of the housing and stock bubbles, and the coefficients of the housing bubble and stock bubble durations are reported in Tables 2 and 3, respectively. All these coefficients are positive and statistically significant at the 5 percent level. The reported results state that bubble episodes as well as bubble durations play an important role in concentrating income among the rich through accumulating capital gains.

The partial slope coefficient of innovation, which is measured by the number of patents per thousand of population on top income shares, is positive and statistically significant at the 5 percent level for both the top $1 \%$ and top $0.1 \%$ shares of total income including capital gains, reported in Tables 2-3. The coefficients of innovation are 0.085 and 0.058 for top $1 \%$ and top $0.1 \%$ shares in total income, respectively. This means that with the influence of other variables held constant, a small increase in innovation is associated with a 0.085 percentage points increase in top $1 \%$ share and a 0.058 percentage points increase in top $0.1 \%$ share. The approximate estimate of elasticity of inequality with respect to innovation is about $0.085 \mathrm{X}(3.861 / 10.887)=0.030$ for top $1 \%$ shares and it is about $0.058 \mathrm{X}(3.861 / 4.101)=$ 0.054 for top $0.1 \%$ shares of total income including capital gains.

Another potential determinant of top income shares, top marginal tax rate is negative and statistically significant at the 5 percent significance level for all the cases reported in Tables 2 and 3. For example, the coefficient of top marginal tax rate is -0.678 for top $1 \%$ share in total income excluding capital gains and the estimate is statistically significant at the 1 percent level. This means that the top income shares of top $1 \%$ can be reduced by 0.678 percent with an additional percentage increase in top marginal tax rate.

The coefficient of top marginal tax rate is also negative and statistically significant at the 5 percent level for the share of capital gains reported in the last two columns of Tables 2 and 3. Table 2 reports that the coefficient of top marginal tax rate is -1.056 for top $1 \%$ share of capital gains, reflecting the effect of top marginal tax rate on top income shares including capital gains, which is 1.056 percent higher in absolute value than the effect of top marginal tax rate on top income shares excluding capital gains. Similarly, for top $0.1 \%$ share of capital gains, the effect of top marginal tax rate on top income shares including capital gains is 0.805 percent higher in absolute value than the effect of top marginal tax rate on top income shares excluding capital gains while comparing a panel of six countries: Canada, Germany, Japan, Spain, Sweden, and USA.

\subsection{Are the Anglo-Saxon and developed countries different?}

As the growth dynamics of the top income shares are quite different, the responses of top incomes to the underlying determinants are not homogeneous between regions. Particularly, the difference is well known in Anglo Saxon countries from the developed and underdeveloped world (e.g., Atkinson and Piketty 2007). Therefore, it would be sensible to estimate the proposed model in each region separately, despite a limitation such as the reduced sample size. It is difficult to estimate the proposed model separately for emerging markets, as 
Table 2 Fixed effect regression estimated for top income shares both including and excluding capital gain. The FGLS estimates excluding capital gain include Australia, Canada, Denmark, Finland, France, Germany, Ireland, Italy, Japan, Korea (R), Netherlands, New Zealand, Norway, South Africa, Spain, Sweden, Switzerland, UK, and USA. Top shares of total income including capital gain include Canada, Germany, Japan, Spain, Sweden, and USA. Share of capital gain is defined as the difference of top shares of total income including capital gain and top shares of total income excluding capital gain

\begin{tabular}{|c|c|c|c|c|c|c|}
\hline \multirow{2}{*}{$\begin{array}{l}\text { Parameter } \\
\text { Estimates }\end{array}$} & \multicolumn{2}{|c|}{ Excluding capital gain } & \multicolumn{2}{|c|}{ Including capital gain } & \multicolumn{2}{|c|}{ Share of capital gain } \\
\hline & Top 1 & Top 0.1 & Top 1 & Top 0.1 & Top 1 & Top 0.1 \\
\hline$y_{i t-1}$ & $\begin{array}{l}0.804^{* * *} \\
(0.028)\end{array}$ & $\begin{array}{l}0.766^{* * *} \\
(0.035)\end{array}$ & $\begin{array}{l}0.673^{* * *} \\
(0.053)\end{array}$ & $\begin{array}{c}0.627^{* * *} \\
(0.058)\end{array}$ & $\begin{array}{c}0.562^{* * *} \\
(0.063)\end{array}$ & $\begin{array}{l}0.575^{* * *} \\
(0.060)\end{array}$ \\
\hline $\begin{array}{l}\text { Stock mrkt. } \\
\text { bubble }\end{array}$ & $\begin{array}{l}0.098 \\
(0.068)\end{array}$ & $\begin{array}{l}0.102^{* * *} \\
(0.039)\end{array}$ & $\begin{array}{l}0.349^{* *} \\
(0.174)\end{array}$ & $\begin{array}{c}0.266^{* *} \\
(0.115)\end{array}$ & $\begin{array}{l}0.269^{* *} \\
(0.136)\end{array}$ & $\begin{array}{l}0.231^{* *} \\
(0.093)\end{array}$ \\
\hline $\begin{array}{l}\text { Stock mrkt. } \\
\text { crash }\end{array}$ & $\begin{array}{l}-0.021 \\
(0.060)\end{array}$ & $\begin{array}{l}0.003 \\
(0.034)\end{array}$ & $\begin{array}{l}-0.230 \\
(0.178)\end{array}$ & $\begin{array}{r}-0.148 \\
(0.117)\end{array}$ & $\begin{array}{r}-0.127 \\
(0.125)\end{array}$ & $\begin{array}{l}-0.115 \\
(0.086)\end{array}$ \\
\hline $\begin{array}{l}\text { Housing mrkt. } \\
\text { bubble }\end{array}$ & $\begin{array}{l}-0.039 \\
(0.068)\end{array}$ & $\begin{array}{l}-0.020 \\
(0.039)\end{array}$ & $\begin{array}{l}0.685^{* * *} \\
(0.204)\end{array}$ & $\begin{array}{c}0.465^{* * *} \\
(0.134)\end{array}$ & $\begin{array}{c}0.483^{* * *} \\
(0.153)\end{array}$ & $\begin{array}{l}0.329^{* * *} \\
(0.104)\end{array}$ \\
\hline $\begin{array}{l}\text { Housing mrkt. } \\
\text { crash }\end{array}$ & $\begin{array}{l}0.130 \\
(0.171)\end{array}$ & $\begin{array}{l}0.064 \\
(0.104)\end{array}$ & $\begin{array}{l}0.170 \\
(0.306)\end{array}$ & $\begin{array}{l}0.103 \\
(0.198)\end{array}$ & $\begin{array}{c}-0.222 \\
(0.229)\end{array}$ & $\begin{array}{l}-0.120 \\
(0.156)\end{array}$ \\
\hline Innovation & $\begin{array}{l}0.030 \\
(0.023)\end{array}$ & $\begin{array}{l}0.026^{*} \\
(0.014)\end{array}$ & $\begin{array}{l}0.085^{* *} \\
(0.033)\end{array}$ & $\begin{array}{c}0.058^{* *} \\
(0.023)\end{array}$ & $\begin{array}{l}0.004 \\
(0.028)\end{array}$ & $\begin{array}{l}0.010 \\
(0.019)\end{array}$ \\
\hline GDPpc & $\begin{array}{l}0.233 \\
(0.478)\end{array}$ & $\begin{array}{l}0.367 \\
(0.261)\end{array}$ & $\begin{array}{l}-2.184^{* *} \\
(0.926)\end{array}$ & $\begin{array}{r}-0.711 \\
(0.588)\end{array}$ & $\begin{array}{l}0.425 \\
(0.634)\end{array}$ & $\begin{array}{l}0.355 \\
(0.425)\end{array}$ \\
\hline $\begin{array}{l}\text { Financial } \\
\text { development }\end{array}$ & $\begin{array}{l}0.304^{\text {*** }} \\
(0.089)\end{array}$ & $\begin{array}{l}0.122^{* *} \\
(0.051)\end{array}$ & $\begin{array}{l}0.001 \\
(0.004)\end{array}$ & $\begin{array}{l}0.001 \\
(0.003)\end{array}$ & $\begin{array}{l}-0.003 \\
(0.003)\end{array}$ & $\begin{array}{l}-0.002 \\
(0.002)\end{array}$ \\
\hline $\begin{array}{l}\text { Government } \\
\text { expenditure }\end{array}$ & $\begin{array}{l}-3.065 \\
(2.130)\end{array}$ & $\begin{array}{l}-2.317^{*} \\
(1.252)\end{array}$ & $\begin{array}{l}-3.362 \\
(4.140)\end{array}$ & $\begin{array}{r}-2.974 \\
(2.735)\end{array}$ & $\begin{array}{c}-0.852 \\
(3.331)\end{array}$ & $\begin{array}{l}-0.168 \\
(2.184)\end{array}$ \\
\hline Openness & $\begin{array}{l}0.053 \\
(0.364)\end{array}$ & $\begin{array}{l}0.002 \\
(0.207)\end{array}$ & $\begin{array}{l}2.266^{* *} \\
(1.081)\end{array}$ & $\begin{array}{l}1.360^{*} \\
(0.706)\end{array}$ & $\begin{array}{l}1.348 \\
(0.861)\end{array}$ & $\begin{array}{l}0.728 \\
(0.575)\end{array}$ \\
\hline Tax rate & $\begin{array}{l}-0.678^{* * *} \\
(0.250)\end{array}$ & $\begin{array}{l}-0.333^{* *} \\
(0.130)\end{array}$ & $\begin{array}{l}-1.217^{* *} \\
(0.528)\end{array}$ & $\begin{array}{c}-0.875^{* *} \\
(0.352)\end{array}$ & $\begin{array}{l}-1.056^{* *} \\
(0.454)\end{array}$ & $\begin{array}{l}-0.805^{* * *} \\
(0.300)\end{array}$ \\
\hline Popupation & $\begin{array}{l}0.773 \\
(0.863)\end{array}$ & $\begin{array}{l}0.612 \\
(0.550)\end{array}$ & $\begin{array}{l}6.092^{* * *} \\
(2.052)\end{array}$ & $\begin{array}{c}4.833^{* * *} \\
(1.403)\end{array}$ & $\begin{array}{l}-0.102 \\
(1.389)\end{array}$ & $\begin{array}{l}0.623 \\
(0.941)\end{array}$ \\
\hline No of obs & 468 & 395 & 182 & 182 & 182 & 182 \\
\hline Countries & 19 & 17 & 6 & 6 & 6 & 6 \\
\hline
\end{tabular}

The table shows the coefficients of the estimation of fixed effect panel regression. The FGLS estimates include both time trend and time invariant country effects. Both time trend and time invariant country effects are not reported in the table. Standard errors are reported in first brackets. The asterisks ***, ** and * refer to $1 \%, 5 \%$ and $10 \%$ levels of significance respectively

the quarterly real housing price indexes are not available in Colombia, India, and Malaysia. The estimates of the proposed model are reported in Table 4.

Financial development, which is measured by the sum of bank deposits and stock market capitalization as a share of GDP, benefits the rich in Anglo-Saxon and developed countries. 
Table 3 Fixed effect regression estimated for top income shares both including and excluding capital gain with duration of explosive episodes. The FGLS estimates excluding capital gain include Australia, Canada, Denmark, Finland, France, Germany, Ireland, Italy, Japan, Korea (R), Netherlands, New Zealand, Norway, South Africa, Spain, Sweden, Switzerland, UK, and USA. Top shares of total income including capital gain include Canada, Germany, Japan, Spain, Sweden, and USA. Share of capital gain is defined as the difference of top shares of total income including capital gain and top shares of total income excluding capital gain

\begin{tabular}{|c|c|c|c|c|c|c|}
\hline \multirow{2}{*}{$\begin{array}{l}\text { Parameter } \\
\text { Estimates }\end{array}$} & \multicolumn{2}{|c|}{ Excluding capital gain } & \multicolumn{2}{|c|}{ Including capital gain } & \multicolumn{2}{|c|}{ Share of capital gain } \\
\hline & Top 1 & Top 0.1 & Top 1 & Top 0.1 & Top 1 & Top 0.1 \\
\hline$y_{i t-1}$ & $\begin{array}{l}0.801^{* * *} \\
(0.029)\end{array}$ & $\begin{array}{l}0.759^{* * *} \\
(0.036)\end{array}$ & $\begin{array}{l}0.616^{* * *} \\
(0.053)\end{array}$ & $\begin{array}{c}0.572^{* * *} \\
(0.055)\end{array}$ & $\begin{array}{c}0.530^{* * *} \\
(0.054)\end{array}$ & $\begin{array}{l}0.530^{* * *} \\
(0.052)\end{array}$ \\
\hline $\begin{array}{l}\text { Stock bubble } \\
\text { duration }\end{array}$ & $\begin{array}{l}0.008 \\
(0.026)\end{array}$ & $\begin{array}{l}0.030^{* *} \\
(0.014)\end{array}$ & $\begin{array}{l}0.242^{* * *} \\
(0.048)\end{array}$ & $\begin{array}{c}0.174^{* * *} \\
(0.031)\end{array}$ & $\begin{array}{c}0.250^{* * *} \\
(0.034)\end{array}$ & $\begin{array}{l}0.176^{* * *} \\
(0.023)\end{array}$ \\
\hline $\begin{array}{l}\text { Stock crash } \\
\text { duration }\end{array}$ & $\begin{array}{l}-0.004 \\
(0.033)\end{array}$ & $\begin{array}{l}0.004 \\
(0.018)\end{array}$ & $\begin{array}{l}-0.099 \\
(0.088)\end{array}$ & $\begin{array}{l}-0.072 \\
(0.057)\end{array}$ & $\begin{array}{l}-0.043 \\
(0.059)\end{array}$ & $\begin{array}{l}-0.053 \\
(0.041)\end{array}$ \\
\hline $\begin{array}{l}\text { Housing bubble } \\
\text { duration }\end{array}$ & $\begin{array}{l}0.006 \\
(0.015)\end{array}$ & $\begin{array}{l}-0.004 \\
(0.011)\end{array}$ & $\begin{array}{l}0.110^{* *} \\
(0.046)\end{array}$ & $\begin{array}{r}0.077^{* *} \\
(0.031)\end{array}$ & $\begin{array}{c}0.100^{* * *} \\
(0.035)\end{array}$ & $\begin{array}{l}0.069^{* * *} \\
(0.024)\end{array}$ \\
\hline $\begin{array}{l}\text { Housing crash } \\
\text { duration }\end{array}$ & $\begin{array}{l}0.059 \\
(0.055)\end{array}$ & $\begin{array}{l}0.023 \\
(0.030)\end{array}$ & $\begin{array}{l}0.027 \\
(0.087)\end{array}$ & $\begin{array}{l}0.015 \\
(0.055)\end{array}$ & $\begin{array}{r}-0.035 \\
(0.057)\end{array}$ & $\begin{array}{l}-0.022 \\
(0.039)\end{array}$ \\
\hline Innovation & $\begin{array}{l}0.028 \\
(0.025)\end{array}$ & $\begin{array}{l}0.027^{*} \\
(0.015)\end{array}$ & $\begin{array}{l}0.074^{* *} \\
(0.031)\end{array}$ & $\begin{array}{r}0.053^{* *} \\
(0.021)\end{array}$ & $\begin{array}{l}-0.010 \\
(0.023)\end{array}$ & $\begin{array}{l}0.004 \\
(0.015)\end{array}$ \\
\hline GDPpc & $\begin{array}{l}0.239 \\
(0.500)\end{array}$ & $\begin{array}{l}0.405 \\
(0.267)\end{array}$ & $\begin{array}{l}-2.749^{* * *} \\
(0.908)\end{array}$ & $\begin{array}{l}-1.086^{* *} \\
(0.551)\end{array}$ & $\begin{array}{l}0.291 \\
(0.529)\end{array}$ & $\begin{array}{l}0.236 \\
(0.356)\end{array}$ \\
\hline $\begin{array}{l}\text { Financial } \\
\text { development }\end{array}$ & $\begin{array}{l}0.310^{* * *} \\
(0.092)\end{array}$ & $\begin{array}{l}0.126^{* *} \\
(0.052)\end{array}$ & $\begin{array}{l}0.000 \\
(0.004)\end{array}$ & $\begin{array}{l}0.001 \\
(0.003)\end{array}$ & $\begin{array}{l}-0.004 \\
(0.003)\end{array}$ & $\begin{array}{r}-0.003 \\
(0.002)\end{array}$ \\
\hline $\begin{array}{l}\text { Government } \\
\text { expenditure }\end{array}$ & $\begin{array}{l}-3.039 \\
(2.130)\end{array}$ & $\begin{array}{l}-1.976 \\
(1.271)\end{array}$ & $\begin{array}{l}-5.802 \\
(3.838)\end{array}$ & $\begin{array}{l}-4.426^{*} \\
(2.466)\end{array}$ & $\begin{array}{l}-2.243 \\
(2.652)\end{array}$ & $\begin{array}{r}-0.933 \\
(1.701)\end{array}$ \\
\hline Openness & $\begin{array}{l}0.073 \\
(0.365)\end{array}$ & $\begin{array}{l}-0.029 \\
(0.211)\end{array}$ & $\begin{array}{l}1.744^{*} \\
(1.034)\end{array}$ & $\begin{array}{l}1.011 \\
(0.664)\end{array}$ & $\begin{array}{l}0.805 \\
(0.747)\end{array}$ & $\begin{array}{l}0.486 \\
(0.487)\end{array}$ \\
\hline Tax rate & $\begin{array}{l}-0.639^{* * *} \\
(0.242)\end{array}$ & $\begin{array}{l}-0.304^{* *} \\
(0.127)\end{array}$ & $\begin{array}{l}-1.121^{* *} \\
(0.506)\end{array}$ & $\begin{array}{l}-0.831^{* *} \\
(0.328)\end{array}$ & $\begin{array}{l}-1.088^{* * *} \\
(0.378)\end{array}$ & $\begin{array}{l}-0.868^{* * *} \\
(0.251)\end{array}$ \\
\hline Popupation & $\begin{array}{l}0.570 \\
(0.893)\end{array}$ & $\begin{array}{l}0.660 \\
(0.557)\end{array}$ & $\begin{array}{l}5.914^{* * *} \\
(1.936)\end{array}$ & $\begin{array}{c}4.720^{* * *} \\
(1.294)\end{array}$ & $\begin{array}{c}-1.441 \\
(1.178)\end{array}$ & $\begin{array}{l}-0.052 \\
(0.783)\end{array}$ \\
\hline No of obs & 468 & 395 & 182 & 182 & 182 & 182 \\
\hline Countries & 19 & 17 & 6 & 6 & 6 & 6 \\
\hline
\end{tabular}

The table shows the coefficients of the estimation of fixed effect panel regression. The FGLS estimates include both time trend and time invariant country effects. Both time trend and time invariant country effects are not reported in the table. Standard errors are reported in first brackets. The asterisks ***,** and * refer to $1 \%, 5 \%$ and $10 \%$ levels of significance respectively

The coefficient of stock market bubble is positive for both the regions but, statistically significant at the 10 percent level only in the Anglo-Saxon region. Both the determinants of top income shares, which are related to the financial sector, have a positive impact on the 
Table 4 Fixed effect regression estimated for top income shares excluding capital gain. Anglo-Saxon countries are Australia, Canada, New Zealand, UK and USA. Developed countries are Denmark, Finland, France, Germany, Ireland, Italy, Japan, Netherlands, Norway, Korea(R), Spain, Sweden and Switzerland

\begin{tabular}{|c|c|c|c|c|}
\hline \multirow{2}{*}{$\begin{array}{l}\text { Parameter } \\
\text { Estimates }\end{array}$} & \multicolumn{2}{|c|}{ Anglo-Saxon } & \multicolumn{2}{|l|}{ Developed } \\
\hline & Top 1 & Top 0.1 & Top 1 & Top 0.1 \\
\hline$y_{i t-1}$ & $\begin{array}{l}0.495^{* * *} \\
(0.079)\end{array}$ & $\begin{array}{l}0.545^{* * *} \\
(0.089)\end{array}$ & $\begin{array}{l}0.735^{\text {*** }} \\
(0.044)\end{array}$ & $\begin{array}{l}0.745^{\text {*** }} \\
(0.059)\end{array}$ \\
\hline $\begin{array}{l}\text { Stock mrkt. } \\
\text { bubble }\end{array}$ & $\begin{array}{l}0.347^{*} \\
(0.186)\end{array}$ & $\begin{array}{l}0.185^{*} \\
(0.106)\end{array}$ & $\begin{array}{l}0.037 \\
(0.076)\end{array}$ & $\begin{array}{l}0.037 \\
(0.044)\end{array}$ \\
\hline $\begin{array}{l}\text { Stock mrkt. } \\
\text { crash }\end{array}$ & $\begin{array}{l}-0.204 \\
(0.223)\end{array}$ & $\begin{array}{l}-0.127 \\
(0.132)\end{array}$ & $\begin{array}{l}-0.035 \\
(0.064)\end{array}$ & $\begin{array}{l}-0.026 \\
(0.037)\end{array}$ \\
\hline Innovation & $\begin{array}{l}0.255^{* * *} \\
(0.052)\end{array}$ & $\begin{array}{l}0.121^{* * *} \\
(0.032)\end{array}$ & $\begin{array}{c}-0.023 \\
(0.030)\end{array}$ & $\begin{array}{l}-0.009 \\
(0.016)\end{array}$ \\
\hline GDPpc & $\begin{array}{l}-6.072^{* *} \\
(2.930)\end{array}$ & $\begin{array}{l}-0.441 \\
(1.692)\end{array}$ & $\begin{array}{l}1.549^{* * *} \\
(0.556)\end{array}$ & $\begin{array}{l}0.600^{* *} \\
(0.280)\end{array}$ \\
\hline $\begin{array}{l}\text { Financial } \\
\text { development }\end{array}$ & $\begin{array}{l}1.292^{* * *} \\
(0.282)\end{array}$ & $\begin{array}{l}0.404^{* *} \\
(0.202)\end{array}$ & $\begin{array}{l}0.373^{* * *} \\
(0.113)\end{array}$ & $\begin{array}{l}0.132^{* *} \\
(0.066)\end{array}$ \\
\hline $\begin{array}{l}\text { Government } \\
\text { expenditure }\end{array}$ & $\begin{array}{l}3.133 \\
(6.819)\end{array}$ & $\begin{array}{l}0.673 \\
(3.668)\end{array}$ & $\begin{array}{l}-1.030 \\
(2.477)\end{array}$ & $\begin{array}{l}-0.745 \\
(1.375)\end{array}$ \\
\hline Openness & $\begin{array}{l}-0.207 \\
(1.683)\end{array}$ & $\begin{array}{l}1.362 \\
(0.964)\end{array}$ & $\begin{array}{l}-0.510 \\
(0.439)\end{array}$ & $\begin{array}{l}-0.064 \\
(0.281)\end{array}$ \\
\hline Tax rate & $\begin{array}{l}-4.442^{* * *} \\
(1.299)\end{array}$ & $\begin{array}{l}-0.736 \\
(0.806)\end{array}$ & $\begin{array}{l}-0.400 \\
(0.294)\end{array}$ & $\begin{array}{c}-0.198 \\
(0.163)\end{array}$ \\
\hline Popupation & $\begin{array}{l}-3.644 \\
(2.808)\end{array}$ & $\begin{array}{l}-2.577 \\
(1.648)\end{array}$ & $\begin{array}{l}-4.357^{* * *} \\
(1.449)\end{array}$ & $\begin{array}{l}-2.074^{* *} \\
(0.980)\end{array}$ \\
\hline $\begin{array}{l}\text { Housing mrkt. } \\
\text { bubble } \\
\text { Housing mrkt. } \\
\text { crash }\end{array}$ & $\begin{array}{l}-0.121 \\
(0.166)\end{array}$ & $\begin{array}{l}-0.095 \\
(0.098)\end{array}$ & $\begin{array}{l}-0.079 \\
(0.081) \\
0.239 \\
(0.171)\end{array}$ & $\begin{array}{l}-0.053 \\
(0.046) \\
0.116 \\
(0.097)\end{array}$ \\
\hline No of obs & 131 & 110 & 319 & 267 \\
\hline Countries & 5 & 5 & 13 & 11 \\
\hline
\end{tabular}

The table shows the coefficients of the estimation of fixed effect panel regression. The FGLS estimates include both time trend and time invariant country effects. Both time trend and time invariant country effects are not reported in the table. Standard errors are reported in first brackets. The asterisks ***, ** and * refer to $1 \%, 5 \%$ and $10 \%$ levels of significance respectively

top income shares, as they disproportionately benefit the rich, eventually widening the top income inequality. However, housing market bubble, housing market crash and stock market crash fail to have any impacts on the top income shares ${ }^{14}$.

\footnotetext{
${ }^{14}$ It is to be noted that financial systems of Anglo-Saxon countries depend on stock market development, and financial development is likely to be correlated with asset market bubbles. For example, the correlation between housing market bubble and financial development is 0.504 in the Anglo-Saxon region.
} 
The coefficient for economic development, measured by the log of GDP per capita, is negative and statistically significant at the 5 percent level in top $1 \%$ shares. The relationship between top income shares and economic growth is still negative, and statistically insignificant, while estimating the proposed model without controlling the effect of financial development in the Anglo-Saxon region. The effect of economic development on top income shares is 1.549 in top $1 \%$ and 0.600 in top $0.1 \%$ and are statically significant at the 5 percent in the developed region. This means that if the GDP per capita goes up by 1 percent, on average, top 1\%'s share in total income goes up by about 1.549 percent and top $0.1 \%$ 's share in total income goes up by about 0.600 percent.

Table 4 reports that the impact of innovation, measured by the partial slope coefficient of innovation is 0.255 for top $1 \%$ share and 0.121 for top $0.1 \%$ share in total income excluding capital gains. Both parameter estimates are significant at the 5 percent level of significance in the Anglo-Saxon region. The coefficient of the variable, central government expenditure is not statistically significant. However, Stack (1978) reports that government spending through government involvement in an economy could eliminate the problem of unemployment, which in turn reduces the degree of income inequality (see also Wolff and Zacharias 2007). Another variable, openness, seems to have no effect on top income inequality in both regions as well.

\section{Robustness checks and extensions}

This section discusses the robustness of the regression results.

\subsection{Alternative measure of bubble and crash}

Occasionally the increases in asset price may gain momentum, which eventually generates bubbles with a different duration. Likewise, the instantaneous decrease in asset price over time strengthens the evolution of crash episodes. Therefore, the indicator variables of bubbles and crashes are substituted with cumulative real returns. To compute cumulative real returns, first a return index series is created by the peak-to-trough procedure and then three years of cumulative returns are calculated for each country separately (see, Barro and Ursúa (2017) for details). Positive cumulative real returns are used as a proxy for the bubble variable and negative cumulative real returns are used as a proxy for the crash variable. The estimated results are reported in Table 5. The coefficients of housing and stock market bubbles are positive and statistically significant at the 5 percent level and crash variables, which are not statistically significant, support the finding of Table 2 . These findings reconfirm that the stock market bubbles are lying behind the recent surge in top income inequality and overall, they are positively correlated with top income shares, despite some drops found in the growth of top income shares.

\subsection{The effect of banking crisis on top income shares}

Financial turmoil, (like debt crisis, inflation crisis, currency crisis, banking crisis and stock market crash) plays an important role in our economic systems and brings substantial losses to the financial sector. Banking crisis, probably one of the most important determinants, is also used in the top income literature to explain the dynamics of top income shares. A comprehensive analysis in this area can be found in Morelli (2018). It is important to note that our paper uses banking crisis, a binary indicator, as a control variable and explains 
Table 5 Fixed effect regression estimated for top income shares both including and excluding capital gain with cumulative asset returns. The FGLS estimates excluding capital gain include Australia, Canada, Denmark, Finland, France, Germany, Ireland, Italy, Japan, Korea (R), Netherlands, New Zealand, Norway, South Africa, Spain, Sweden, Switzerland, UK, and USA. Top shares of total income including capital gain include Canada, Germany, Japan, Spain, Sweden, and USA

\begin{tabular}{|c|c|c|c|c|c|c|c|c|}
\hline \multirow{3}{*}{$\begin{array}{l}\text { Parameter } \\
\text { Estimates }\end{array}$} & \multicolumn{4}{|c|}{ Excluding capital gain } & \multicolumn{4}{|c|}{ Including capital gain } \\
\hline & \multicolumn{2}{|l|}{ Top 1} & \multicolumn{2}{|l|}{ Top 0.1} & \multicolumn{2}{|l|}{ Top 1} & \multicolumn{2}{|c|}{ Top 0.1} \\
\hline & Model 1 & Model 2 & Model 1 & Model 2 & Model 1 & Model 2 & Model 1 & Model 2 \\
\hline$y_{i t-1}$ & $\begin{array}{l}0.807^{* * *} \\
(0.028)\end{array}$ & $\begin{array}{l}0.806^{* * *} \\
(0.028)\end{array}$ & $\begin{array}{c}0.760^{* * *} \\
(0.037)\end{array}$ & $\begin{array}{l}0.763^{* * *} \\
(0.037)\end{array}$ & $\begin{array}{l}0.642^{* * *} \\
(0.056)\end{array}$ & $\begin{array}{l}0.620^{* * *} \\
(0.057)\end{array}$ & $\begin{array}{l}0.594^{* * *} \\
(0.060)\end{array}$ & $\begin{array}{c}0.580^{* * *} \\
(0.060)\end{array}$ \\
\hline $\begin{array}{l}(+) \text { ve cum. ret } \\
\text { stock market }\end{array}$ & $\begin{array}{l}0.305^{* * *} \\
(0.077)\end{array}$ & $\begin{array}{l}0.305^{* * *} \\
(0.077)\end{array}$ & $\begin{array}{l}0.105^{* *} \\
(0.052)\end{array}$ & $\begin{array}{l}0.109^{* *} \\
(0.052)\end{array}$ & $\begin{array}{c}0.825^{* * *} \\
(0.268)\end{array}$ & $\begin{array}{l}0.724^{* * *} \\
(0.266)\end{array}$ & $\begin{array}{l}0.571^{* * *} \\
(0.176)\end{array}$ & $\begin{array}{l}0.505^{* * *} \\
(0.174)\end{array}$ \\
\hline $\begin{array}{l}(-) \text { ve cum } \\
\text { stock market }\end{array}$ & $\begin{array}{l}0.007 \\
(0.227)\end{array}$ & $\begin{array}{l}0.008 \\
(0.230)\end{array}$ & $\begin{array}{l}-0.027 \\
(0.125)\end{array}$ & $\begin{array}{l}-0.002 \\
(0.128)\end{array}$ & $\begin{array}{r}-0.831 \\
(0.678)\end{array}$ & $\begin{array}{l}-0.704 \\
(0.675)\end{array}$ & $\begin{array}{l}-0.589 \\
(0.448)\end{array}$ & $\begin{array}{l}-0.527 \\
(0.445)\end{array}$ \\
\hline $\begin{array}{l}(+) \text { ve cum. ret } \\
\text { housing mrkt. }\end{array}$ & $\begin{array}{l}-0.346 \\
(0.271)\end{array}$ & $\begin{array}{l}-0.334 \\
(0.273)\end{array}$ & $\begin{array}{l}-0.228 \\
(0.166)\end{array}$ & $\begin{array}{r}-0.244 \\
(0.166)\end{array}$ & $\begin{array}{c}2.423^{* * *} \\
(0.846)\end{array}$ & $\begin{array}{l}2.311^{* * *} \\
(0.850)\end{array}$ & $\begin{array}{l}1.520^{* * *} \\
(0.559)\end{array}$ & $\begin{array}{l}1.442^{* *} \\
(0.560)\end{array}$ \\
\hline $\begin{array}{l}\text { (-) ve cum. ret } \\
\text { housing mrkt. }\end{array}$ & $\begin{array}{l}0.345 \\
(0.271)\end{array}$ & $\begin{array}{l}0.333 \\
(0.273)\end{array}$ & $\begin{array}{l}0.230 \\
(0.166)\end{array}$ & $\begin{array}{l}0.245 \\
(0.166)\end{array}$ & $\begin{array}{l}0.427 \\
(1.037)\end{array}$ & $\begin{array}{l}-0.340 \\
(1.082)\end{array}$ & $\begin{array}{l}0.104 \\
(0.686)\end{array}$ & $\begin{array}{l}-0.340 \\
(0.715)\end{array}$ \\
\hline Innovation & $\begin{array}{l}0.038 \\
(0.023)\end{array}$ & $\begin{array}{l}0.036 \\
(0.023)\end{array}$ & $\begin{array}{r}0.030^{* *} \\
(0.014)\end{array}$ & $\begin{array}{l}0.031^{* *} \\
(0.014)\end{array}$ & $\begin{array}{l}0.079^{* * *} \\
(0.031)\end{array}$ & $\begin{array}{l}0.077^{* *} \\
(0.031)\end{array}$ & $\begin{array}{l}0.054^{* *} \\
(0.021)\end{array}$ & $\begin{array}{c}0.053^{* *} \\
(0.021)\end{array}$ \\
\hline GDPpc & $\begin{array}{l}0.284 \\
(0.474)\end{array}$ & $\begin{array}{l}0.247 \\
(0.470)\end{array}$ & $\begin{array}{l}0.322 \\
(0.270)\end{array}$ & $\begin{array}{l}0.421 \\
(0.279)\end{array}$ & $\begin{array}{l}-1.557 \\
(1.041)\end{array}$ & $\begin{array}{l}-1.661^{*} \\
(0.994)\end{array}$ & $\begin{array}{l}-0.376 \\
(0.680)\end{array}$ & $\begin{array}{r}-0.400 \\
(0.641)\end{array}$ \\
\hline $\begin{array}{l}\text { Financial } \\
\text { development }\end{array}$ & $\begin{array}{l}0.254^{* * *} \\
(0.090)\end{array}$ & $\begin{array}{l}0.254^{* * *} \\
(0.090)\end{array}$ & $\begin{array}{l}0.145^{* * *} \\
(0.050)\end{array}$ & $\begin{array}{c}0.143^{* * *} \\
(0.051)\end{array}$ & $\begin{array}{l}0.001 \\
(0.004)\end{array}$ & $\begin{array}{l}0.002 \\
(0.004)\end{array}$ & $\begin{array}{l}0.001 \\
(0.002)\end{array}$ & $\begin{array}{l}0.001 \\
(0.003)\end{array}$ \\
\hline $\begin{array}{l}\text { Government } \\
\text { expenditure }\end{array}$ & $\begin{array}{l}-2.872 \\
(2.019)\end{array}$ & $\begin{array}{l}-2.535 \\
(1.999)\end{array}$ & $\begin{array}{l}-2.269^{*} \\
(1.279)\end{array}$ & $\begin{array}{l}-2.308^{*} \\
(1.292)\end{array}$ & $\begin{array}{l}-5.429 \\
(4.160)\end{array}$ & $\begin{array}{l}-7.676^{*} \\
(4.330)\end{array}$ & $\begin{array}{l}-4.660^{*} \\
(2.700)\end{array}$ & $\begin{array}{l}-5.935^{* *} \\
(2.783)\end{array}$ \\
\hline Openness & $\begin{array}{l}0.129 \\
(0.364)\end{array}$ & $\begin{array}{l}0.115 \\
(0.365)\end{array}$ & $\begin{array}{l}0.005 \\
(0.212)\end{array}$ & $\begin{array}{l}-0.001 \\
(0.211)\end{array}$ & $\begin{array}{l}2.634^{* * *} \\
(0.926)\end{array}$ & $\begin{array}{l}2.140^{* *} \\
(0.996)\end{array}$ & $\begin{array}{l}1.448^{* *} \\
(0.611)\end{array}$ & $\begin{array}{l}1.162^{*} \\
(0.655)\end{array}$ \\
\hline Tax rate & $\begin{array}{l}-0.725^{* * *} \\
(0.246)\end{array}$ & $\begin{array}{l}-0.727^{* * *} \\
(0.250)\end{array}$ & $\begin{array}{l}-0.364^{* * *} \\
(0.125)\end{array}$ & $\begin{array}{l}-0.350^{* * *} \\
(0.125)\end{array}$ & $\begin{array}{l}-1.659^{* * *} \\
(0.483)\end{array}$ & $\begin{array}{l}-2.074^{* * *} \\
(0.538)\end{array}$ & $\begin{array}{l}-1.212^{* * *} \\
(0.315)\end{array}$ & $\begin{array}{c}-1.473^{* * *} \\
(0.350)\end{array}$ \\
\hline Popupation & $\begin{array}{l}0.653 \\
(0.898)\end{array}$ & $\begin{array}{l}0.616 \\
(0.905)\end{array}$ & $\begin{array}{l}0.829 \\
(0.592)\end{array}$ & $\begin{array}{l}0.803 \\
(0.596)\end{array}$ & $\begin{array}{l}9.064^{* * *} \\
(2.027)\end{array}$ & $\begin{array}{l}9.172^{* * *} \\
(2.031)\end{array}$ & $\begin{array}{l}6.735^{* * *} \\
(1.374)\end{array}$ & $\begin{array}{c}6.836^{* * *} \\
(1.376)\end{array}$ \\
\hline $\begin{array}{l}\text { Banking } \\
\text { crisis }\end{array}$ & & $\begin{array}{l}-0.030 \\
(0.061)\end{array}$ & & $\begin{array}{l}0.039 \\
(0.036)\end{array}$ & & $\begin{array}{l}-0.314^{*} \\
(0.167)\end{array}$ & & $\begin{array}{l}-0.202^{*} \\
(0.110)\end{array}$ \\
\hline No of obs & 468 & 468 & 395 & 395 & 182 & 182 & 182 & 182 \\
\hline Countries & 19 & 19 & 17 & 17 & 6 & 6 & 6 & 6 \\
\hline
\end{tabular}

The table shows the coefficients of the estimation of fixed effect panel regression with cumulative asset returns. The FGLS estimates of Model 1 and 2 include both time trend and time invariant country effects. Both time trend and time invariant country effects are not reported in the table. Standard errors are reported in first brackets. The asterisks $* * *, * *$ and $*$ refer to $1 \%, 5 \%$ and $10 \%$ levels of significance respectively

transitory effects of banking crisis on top income shares, while estimating the proposed model. The impact of banking crisis on top $0.1 \%$ and top $1 \%$ shares in total income is reported in Table 5. The coefficient of banking crisis is -0.314 for top $1 \%$ and it is -0.202 for 
top $0.1 \%$ 's share in total income (including capital gains). Both coefficients are statistically significant at the 10 percent level. The result means that the top 1\%'s share in total income (including capital gains) goes down by 0.314 percentage points and the top $0.1 \%$ 's share in total income (including capital gains) goes down by 0.202 percentage points during the episodes of banking crisis in comparison to the non- banking crisis episodes. The effect of banking crisis is not statistically significant for top income shares excluding capital gains. Financial development and GDP per capita are likely to be correlated with banking crisis. Therefore, the proposed model is estimated without including the direct controls of these variables. Unreported results suggest that the effect of banking crisis is still not statistically significant for top income shares excluding capital gains, which supports the preliminary findings reported in Table 1, Panel B. Estimated results, however, should be interpreted with caution and further research is needed to infer the impact of banking crisis on top income shares (see Roine et al. (2009), Morelli 2018).

\subsection{The effect of other variables on top income shares}

There are some discrepancies while comparing the results of Tables 2 and 5 with the results of Table 4. The effect of GDP per capita is negative in the Anglo-Saxon countries but is positive for developed countries, but Table 2 reports that the overall impact of GDP per capita on top income shares is statistically insignificant. The coefficient of top marginal tax rate is negative and statistically significant at the 5 percent level, reported in Tables 2 and 5. Contrary to these findings, Table 4 states that the top marginal tax rate fails to reduce the recent surge in top income shares in developed countries. Similarly, innovation is likely to favour the rich as the coefficient of innovation is positive in Tables 2-3. The impact of innovation on top income shares is positive, but statistically insignificant in the developed region, reported in Table 4. Other variables, government expenditure and openness, may have no impact in explaining the dynamics of top income shares (see Table 4), but Tables 2 and 5 demonstrate that the variable, central government expenditure, seems to have a negative impact on top income inequality. Another variable, trade openness, probably plays an important role in explaining the recent surge in top income shares (including capital gains). The positive effect of openness on top income shares supports the findings of Calderon and Chong (2001).

Despite some variations about the impact of control variables on top income shares, the quality of estimated results, particularly the impact of bubble on top income shares is positive and robust. It is also important to note that the small sample size is a limitation, and the value of the standard error is directly dependent on the sample size. Additionally, the proposed model includes a lagged dependent variable that could be correlated with the unobserved fixed effects. Therefore, estimated results might be biased, and the bias is reduced when sample size is large (Nickell 1981). Therefore, the estimated results need to be interpreted carefully.

\section{Concluding remarks}

The rise in top income shares over the last three decades in many advanced countries has been, to a significant extent, a consequence of a series of asset-price bubbles. Empirical 
results show that correlation between asset bubbles and top inequality is positive and significant. The regression coefficient of stock and housing market bubbles have a positive effect on top income shares, while the stock and housing market crashes fail to reduce the surge in top income shares. The innovation variable, measured by the annual flow of patents, has a positive impact on the top income shares. Its impact on the top shares is much more visible when capital gains are counted as income. Top marginal tax rates also play an important role in impeding the surge in income shares. In summary: asset bubbles as well as top marginal tax rates and innovation-led growth, are among the most important determinants of the increasing shares of top income earners that many developed countries have experienced over the past few decades.

\section{Appendix A}

\section{A.1 Basic explanatory variables}

Table 6 Description of variables and data sources

\begin{tabular}{|c|c|c|}
\hline Top1 & $\begin{array}{l}\text { Share of total income earned by those with } \\
\text { the } 1 \% \text { highest incomes (P99-P100). }\end{array}$ & $\begin{array}{l}\text { World Wealth and } \\
\text { Income Database (WID) }\end{array}$ \\
\hline Top0.1 & $\begin{array}{l}\text { Share of total income earned by those with } \\
\text { the } 0.1 \% \text { highest incomes (P99.9-P100). }\end{array}$ & WID (wid.world) \\
\hline $\begin{array}{l}\text { Gross domestic } \\
\text { product-PC }\end{array}$ & $\begin{array}{l}\text { Log of real gross domestic product per capita. } \\
\text { (constant } 2011 \text { US\$) }\end{array}$ & http://www.ggdc.net \\
\hline Innovation & $\begin{array}{l}\text { Number of total patents granted at the European } \\
\text { patent office (EPO) per thousand of people. }\end{array}$ & OECD database \\
\hline $\begin{array}{l}\text { Real stock } \\
\text { market price }\end{array}$ & $\begin{array}{l}\text { Quarterly real stock-price composite } \\
\text { index. }\end{array}$ & Global Financial Database \\
\hline $\begin{array}{l}\text { Real housing } \\
\text { market price }\end{array}$ & Quarterly real housing-price index. & $\begin{array}{l}\text { dallasfed.org/institute } \\
\text { /houseprice }\end{array}$ \\
\hline $\begin{array}{l}\text { Financial } \\
\text { development }\end{array}$ & $\begin{array}{l}\text { T. market capitalization as the sum of bank deposits } \\
\text { and stock market capitalization divided by GDP. }\end{array}$ & $\begin{array}{l}\text { Roine et al. (2009) and } \\
\text { WB, FSD database }\end{array}$ \\
\hline Tax rate & $\begin{array}{l}\text { Top marginal tax: statutory tax rate for each } \\
\text { available country. }\end{array}$ & $\begin{array}{l}\text { Roine et al. (2009), OECD } \\
\text { database (Table 1.7) and } \\
\text { S.A. Rev.service (2010-11) }\end{array}$ \\
\hline Openness & Import plus export divided by GDP. & $\begin{array}{l}\text { Roine et al. (2009) and } \\
\text { World Bank (WB) database }\end{array}$ \\
\hline $\begin{array}{l}\text { Government } \\
\text { expenditure }\end{array}$ & Central govt. expenditure divided by GDP. & $\begin{array}{l}\text { Roine et al. (2009) and } \\
\text { updated from WB database }\end{array}$ \\
\hline $\begin{array}{l}\text { Stock market } \\
\text { crash }\end{array}$ & $\begin{array}{l}\text { It is a binary variable which takes the value of } 1 \\
\text { for crash episodes and zero otherwise. }\end{array}$ & carmenreinhart.com \\
\hline $\begin{array}{l}\text { Stock/housing } \\
\text { market bubble }\end{array}$ & $\begin{array}{l}\text { It is a binary variable which takes the value of } 1 \\
\text { for bubble episodes and zero otherwise. }\end{array}$ & $\begin{array}{l}\text { Based on GSADF statistical } \\
\text { method }\end{array}$ \\
\hline $\begin{array}{l}\text { Housing market } \\
\text { crash }\end{array}$ & $\begin{array}{l}\text { It is a binary variable which takes the value of } 1 \\
\text { for crash episodes and zero otherwise. }\end{array}$ & $\begin{array}{l}\text { Based on GSADF statistical } \\
\text { method }\end{array}$ \\
\hline
\end{tabular}


Table 6 (continued)

\begin{tabular}{lll}
\hline $\begin{array}{l}\text { Bubble/crash } \\
\text { duration }\end{array}$ & $\begin{array}{l}\text { Duration is defined by the year-to-burst of the } \\
\text { explosive episodes in the asset markets. }\end{array}$ & $\begin{array}{l}\text { Based on GSADF statistical } \\
\text { and carmenreinhart.com }\end{array}$ \\
Banking & $\begin{array}{l}\text { It is a binary variable which takes the value of 1 } \\
\text { for crisis episodes and zero otherwise. }\end{array}$ & $\begin{array}{l}\text { carmenreinhart.com and WB, } \\
\text { crisis }\end{array}$ \\
Population & Log of total population. & http://www.ggdc.net
\end{tabular}

Table 7 Top income shares from World Wealth and Income Database. The sample periods of top income shares including capital gain are reported in brackets

\begin{tabular}{|c|c|c|c|c|c|}
\hline \multirow[b]{2}{*}{ Country } & \multicolumn{2}{|l|}{ Sample period } & \multirow[b]{2}{*}{ Country } & \multicolumn{2}{|l|}{ Sample period } \\
\hline & Top1 & Top0.1 & & Top1 & Top0.1 \\
\hline Australia & $1980-2010$ & $1980-2010$ & Malaysia & $1988-2011^{\mathrm{a}}$ & $1988-1995^{\mathrm{a}}$ \\
\hline Canada & $\begin{array}{l}1980-2010 \\
(1980-2010)\end{array}$ & $\begin{array}{l}1980-2010 \\
(1980-2010)\end{array}$ & Netherlands & $1980-2012^{\mathrm{a}}$ & $1980-1999^{a}$ \\
\hline Colombia & 1993-2010 & $1993-2010^{a}$ & New Zealand & $1985-2011$ & 1985-1989 \\
\hline Denmark & 1980-2010 & $1980-2010$ & Norway & $1980-2011$ & 1980-2011 \\
\hline Finland & 1983-2009 & na & Singapore & $1989-2011^{\mathrm{a}}$ & $1989-2011^{\mathrm{a}}$ \\
\hline France & 1980-2012 & $1980-2012^{\mathrm{a}}$ & South Africa & $\begin{array}{l}1980-1993^{\mathrm{a}} \\
2002-2011\end{array}$ & $\begin{array}{l}1980-1993^{\mathrm{a}} \\
2002-2011\end{array}$ \\
\hline Germany & $\begin{array}{l}1980-2008^{\mathrm{a}} \\
\left(1980-2008^{\mathrm{a}}\right)\end{array}$ & $\begin{array}{l}1980-2008^{\mathrm{a}} \\
\left(1980-2008^{\mathrm{a}}\right)\end{array}$ & Spain & $\begin{array}{l}1981-2011 \\
(1981-2011)\end{array}$ & $\begin{array}{l}1981-2011 \\
(1981-2011)\end{array}$ \\
\hline India & 1980-1999 & 1980-1999 & Sweden & $\begin{array}{l}1980-2012 \\
(1980-2012)\end{array}$ & $\begin{array}{l}1980-2012 \\
(1980-2012)\end{array}$ \\
\hline Ireland & 1995-2009 & na & Switzerland & $1980-2010^{\mathrm{a}}$ & $1980-2010^{a}$ \\
\hline Italy & $1980-2007^{\mathrm{a}}$ & $1980-2007^{a}$ & UK & $1980-2012^{\mathrm{a}}$ & $1980-2012^{\mathrm{a}}$ \\
\hline Japan & $\begin{array}{l}1980-2010 \\
(1980-2010)\end{array}$ & $\begin{array}{l}1980-2010 \\
(1980-2010)\end{array}$ & USA & $\begin{array}{l}1980-2012 \\
(1980-2012)\end{array}$ & $\begin{array}{l}1980-2012 \\
(1980-2012)\end{array}$ \\
\hline Korea(R) & 1995-2011 & $1995-2011$ & & & \\
\hline
\end{tabular}

${ }^{a}$ There are not more than five consecutive years with missing values in this subperiod. Linear interpolation could be used between these years while estimating the model

Supplementary Information The online version contains supplementary material available at https://doi.org/10.1007/s10888-021-09481-y.

Acknowledgements We would like to thank the editor and two anonymous referees for their extremely helpful comments and suggestions. We have also benefited from comments from Daniel Waldenström, Andrew Leigh, Jukka Pirttilä, Kari Heimonen, Hannu Tanninen, Nabil Tahani, Craig Brett, José F. Ursúa and Wojciech Kopczuk. Financial support from the Marjorie Young Bell Faculty Fund and the Academy of Finland Strategic Research Council project Work, Inequality and Public Policy (number 293120) are gratefully acknowledged. 
Open Access This article is licensed under a Creative Commons Attribution 4.0 International License, which permits use, sharing, adaptation, distribution and reproduction in any medium or format, as long as you give appropriate credit to the original author(s) and the source, provide a link to the Creative Commons licence, and indicate if changes were made. The images or other third party material in this article are included in the article's Creative Commons licence, unless indicated otherwise in a credit line to the material. If material is not included in the article's Creative Commons licence and your intended use is not permitted by statutory regulation or exceeds the permitted use, you will need to obtain permission directly from the copyright holder. To view a copy of this licence, visit http://creativecommons.org/licenses/by/4.0/.

\section{References}

Aghion, P., Akcigit, U., Bergeaud, A., Blundell, R., Hemous, D.: Innovation and top income inequality. Rev. Econ. Stud. 86, 1-45 (2019)

Arellano, M., Bond, S.: Some tests of specification for panel data: Monte Carlo evidence and an application to employment equations. Rev. Econ. Stud. 58, 277-298 (1991)

Arellano, M., Bover, O.: Another look at instrumental variables estimation of error components models. J. Econ. 68, 29-51 (1995)

Atkinson, A.B.: Comparing the distribution of top incomes across countries. J. Eur. Econ. Assoc. 3, 393-401 (2005)

Atkinson, A.B., Piketty, T.: Top incomes over the twentieth century: A contrast between Continental European and English-Speaking countries. Oxford University Press, Oxford (2007)

Atkinson, A.B., Leigh, A.: The distribution of top incomes in five Anglo-Saxon countries over the twentieth century. Econ. Rec. 89, 31-47 (2013)

Barro, R., Ursúa, J.: Stock-market crashes and depressions. Res. Econ. 71, 384-398 (2017)

Bertrand, M., Duflo, E., Mullainathan, S.: How much should we trust differences-in-differences estimates? Q. J. Econ. 119, 249-275 (2004)

Calderon, C., Chong, A.: External Sector and Income Inequality in Independent Economies using dynamic panel data approach. Econ. Lett. 71, 225-231 (2001)

Chen, H., Quan, L.: Rational speculative bubbles in the Asian stock markets: Tests on deterministic explosive bubbles and stochastic explosive root bubbles. J. Asset Manag. 14, 195-208 (2013)

Corbeta, S., Lucey, B., Yarovayac, L.: Datestamping the Bitcoin and Ethereum bubbles. Finance Res. Lett. 26, 81-88 (2018)

Financial Structure Database (FSD) Updated version of Beck, Demirgüç-kunt, T.A., Levine, R.: A new database on financial development and structure. World Bank Econ. Rev. 14, 597-605 (2013)

Guellec, M., Paunov, C.: Digital Innovation and the disytibution of income. Working paper 23987 National Bureau of Economic Research (2017)

Homm, U., Breitung, J.: Testing for speculative bubbles in stock markets: a comparison of alternative methods. J. Financ. Econ. 10, 198-231 (2012)

Klomp, J.: Causes of banking crises revisited. North Amer. J. Econ. Financ. 21, $72-87$ (2010)

Kurz, M.: On the formation of capital and wealth: IT, Monopoly Power and Rising Inequality. Working Paper 17-016, Economics Department Stanford University (2017)

Mack, A., Gracia, E.: Cross-Country Quarterly Database of Real House Prices: A Methodological Note Working Paper 99, Federal Reserve Bank of Dallas, Globalization and Monetary Policy Institute (2015)

Morelli, S., Atkinson, A.B.: Inequality and crises revisited. Econ. Polit. 32, 31-51 (2015)

Morelli, S.: Banking crises in the US: the response of top income shares in a historical perspective. J. Econ. Inequal. 16, 257-294 (2018)

Nickell, S.: Biases in dynamic models with fixed effects. Econometrica 49, 1399-1416 (1981)

Pavlidis, E., Alisa, Y., Ivan, P., David, P., Enrique, M.-G., Adrienne, M., Valerie, G., et al.: Monitoring Housing Markets for Episodes of Exuberance: an Application of the Phillips. (2012, 2013) GSADF Test on the Dallas Fed International House Price Database. Working Paper 165, Federal Reserve Bank of Dallas, Globalization and Monetary Policy Institute (2015)

Phillips, P.C., Shi, S.-P., Yu, J.: Testing for multiple bubbles: Historical episodes of exuberance and collapse in the S\&P 500. Int. Econ. Rev. 56, 1043-1078 (2015)

Piketty, T., Saez, E.: How progressive is the U.S. federal tax system? a historical and international perspective. J. Econ. Perspect. 21, 1-24 (2007)

Piketty, T., Saez, E., Stantcheva, S.: Optimal taxation of top labor incomes: a tale of three elasticites. Amer. Econ. J. Econ. Policy 6, 230-271 (2014) 
Reinhart, C.M., Rogoff, K.S.: From financial crash to debt crisis. Amer. Econ. Rev. 101, 1676-1706 (2011)

Roine, J., Vlachos, J., Waldenstrom, D.: The long run determinants of inequality: What can we learn from top income data? J. Public Econ. 93, 967-988 (2009)

Roodman, D.: How to do xtabond2: an introduction to 'difference' and 'system' GMM in stata. Center for Global Development Working Paper 103 (2007)

Stack, S.: The effect of direct government involvement in the economy on the degree of income inequality: a cross-national study. Am. Sociol. Rev. 43, 880-888 (1978)

Wolff, E.N., Zacharias, A.: The distributional consequences of government spending and taxation in the U.S., 1989 and 2000. Rev. Income Wealth 53, 692-715 (2007)

Zeren, F., Yilanci, V.: Are there Multiple Bubbles in the Stock Markets? Further Evidence from Selected Countries. Ekonomika 98, 81-95 (2019)

Publisher's note Springer Nature remains neutral with regard to jurisdictional claims in published maps and institutional affiliations. 